\title{
Career Development Services (CDS) at the University Level: A Study on Two Private Universities in Bangladesh
}

\author{
MOHAMMAD MASUDUR RAHMAN*
}

\begin{abstract}
In this paper an attempt has been made to analyze the importance of educating students through various missions of professional development activities of a university. Through its focus on teaching and learning, research and discovery, and outreach and engagement, the university creates, conveys, and applies knowledge to expand personal growth and opportunity, advance social and community development, foster economic competitiveness, and improve quality of life. Bangladesh, as a developing nation, experiences one of the most acute unemployment situations in the world. Getting a suitable job or building right career in the expected way has now-a-days become very difficult. Emphasis has been given on building skilled human resources by undertaking job oriented academic programs, arranging internship, job placement, workshop and facilitating opportunities to study abroad for higher education. Because, without imparting qualitative education and proper counseling a fresh graduate may lose the right way to approach in getting a better livelihood and build healthier career. The university, where the students are taught, can play a pivotal role in guiding them and building their professional skills in the way of achieving the goal. This article will analyze how a university can take part with students' professional development activities and prepares its students for job market at home and abroad.
\end{abstract}

Key words: Career Development, Career Planning, Professional Development, Internship, CDS.

\section{INTRODUCTION}

Building right career or getting a suitable job in the expected way has now-adays become very challenging. Career is a common phenomenon to everyone. We know that people sometimes have difficulties in achieving their career goals. Career development is undeniably significant to us all to address unemployment

\footnotetext{
* Assistant Professor, Faculty of Business Administration, European University of Bangladesh (EUB), Dhaka
} 
problem, the number one quandary in Bangladesh. As a result, career development has been an important topic in HRM-related courses for several decades. Career development looks at the long-term career effectiveness. Years ago, career development programs were designed to assist employees in advancing their work lives. But the expectation and need are changing fast.

Educational institutions, universities in particular, shape the knowledge, skill and attitude of individuals and are prime movers in the transfer of appropriate learning for self-development (Leila D. Landicho,2001). The first university of the world, The University of Al-Karaouine or Al-Qarawiyyin, located in Fes, Morocco was founded in 859 A.D. to act as spiritual and educational center of the Muslim world. The university played a leading role in the cultural and academic relations between the Islamic world and Europe in the middle ages (www.englishbaby.com/forum/LifeTalk/thread/435142). But in course of time the vision and mission of a university have changed to meet the challenges of professional development. University supports communities working on equitable, democratic, and sustainable development in the country where it operates as well as globally. The mission of a university is to be a focal point for learning, planning, and cultural change for fulfilling the commitment (http://www.campusservices.harvard.edu/mission-statement). Emphasis has been given on "learning by doing," on combining liberal and professional education, and on the value of useful knowledge, continues to be at the heart of educational mission (web.mit.edu/mission.html).

Universities in Bangladesh are mainly categorized into three different types Public (government-owned and subsidized), Private (private sector-owned universities), and International (operated and funded by international organizations). Nevertheless, access to tertiary level education in Bangladesh is still very limited. Only about 12 percent of the students can complete higher education. Tertiary education in Bangladesh takes place only at thirty-four government and seventy-eight private universities (http://www.ugc.gov.bd./ university/?action=international). Students can choose to get their studies in different disciplines at a variety of universities and also from colleges under the National University. These students get admitted not only for acquiring knowledge but also for building career. Instances are available both in the developed and developing world that universities are serving the graduates in developing their career. The future careerists i.e. a university graduates must be prepared to do whatever is necessary to advance career. The essence of a contemporary career development program is to provide support to graduates of a university; continually add to their skills, abilities, and knowledge. But it is 
observed that few universities are organizing career development programs for their students in Bangladesh.

This study focuses on two private universities i.e. BRAC University, Dhaka, Bangladesh and North South University, Dhaka. Bangladesh have already realized the importance of preparing students for competitive job markets and started to counsel for developing the potentials of the students to make them proficient for job market through Career Development Services (CDS).The main objective of this study is to identify the importance of educating students through various missions of professional development activities of a university. The specific objectives are:

i. To sketch how a Career Development Services wing of a university can help students providing employment opportunities in a true manner.

ii. To examine whether university can make the wisdom, talents and intelligence of the graduates more useful to present job markets as well as to the potential employers.

\section{LITERATURE REVIEW}

In absence of a serious academic review such an important issue remained in abeyance. To do this study, we have reviewed national and international literatures on career development services wing of universities. We also remained conscious about literature selection and review. Among the reviewed literature, some major findings can be illustrated which are more relevant with CDS to make the wisdom, talents and intelligence of the graduates more useful to present job markets in Bangladesh.

In reviewing the literature, the researchers found varieties of definition of career in terms of society, community and group of people discussed by the academics and researchers. In popular usage it can mean advancement ('He's moving up in his career'), a profession (She's chosen a career in medicine'), or stability over time (David A. DeCenzo and Stephen P. Robbins, 2007). For our purposes, we define career as "the pattern of work-related experiences that span the course of a person's life." (D.T. Hall,1976). The sequence of positions that a person has held over his or her life is career (Santa Monica, 1977). In addition to formal job, career can include schoolwork, homemaking, or volunteer work. Furthermore, career success is defined not only objectively, in terms of promotion, but also subjectively, in terms of satisfaction. 
Career Development Services (CDS) at university takes for itself, as the chief mission to prepare students for job market (J.H. Greenhaus, 1987). CDS offers the Career Advantage Programs (CAP) to students, the Alumni Advantage Program (AAP) for graduates and Recruiting Advantage Partnerships (RAP) to employers through a variety of programs, workshops, arranging career fair and individual counseling opportunities to help students to develop themselves professionally (Career Service Handbook, BRAC University, 2010). CDS provides a knowledge base in career planning skills and tools. The activities at CDS are partnership-oriented for making a match between the individual student and the employing organization. All these activities consist of a full array of career development programs and services (Miah, M Khasro, 2013).

Many large employers have college recruiting programs that target certain colleges and universities (Luis R. Gomez-Mejia, 2000). Students themselves are also proactive to contribute using their latent. Instances are available in both the developed and developing countries. In Japan, where some large companies offer lifetime employment, college recruitment is practically the only way employers can bring in new blood. Competition among college students to gain access to the largest companies is fierce. For instance, college students are routinely sent"Information request postcards" to prospective employers beginning in December of their junior year. A student may mail well over 1,000 cards to the employers, with 40 to 50 cards are sent to employers by the students who really want to impress. The companies send an invitation to students to come to the company's "information sessions"(Yamamoto, T, 1993). North South University (NSU) is the first private university in Bangladesh that established the Department of Career and Professional Development Services (CPDS) to provide a multifaceted support system to its graduate's career (8th National Career Fair Handbook, NSU, June, 2013, p.26-37). The other private university named BRAC University is seen very caring to support their students in providing support on employment opportunities. As a corporate stakeholder both of them participated in some of that career fairs and observed their strategy to help the students which were highly momentous. The activities of CDS of both universities include career counseling / developing educational and career goals, resume writing, career fair and events, conference arrangement, graduate survey, corporate presentation, finding part-time \& full-time employment, job listing/ meeting with the corporate sectors to learn about the new job openings and needs, preparing students for admission into prestigious foreign universities for higher studies, providing linkages of international career opportunities, maintaining alumni relations (8th National Career Fair Handbook, NSU, June, 2013, p.26-37 and Annual Report, BRAC University, 2010). 


\section{METHODOLOGY}

We have used both primary and secondary sources of information in carrying out this work. A combination of qualitative and quantitative approach is used to attain the objectives of the study (Creswell, John W., 2003). For the purpose of this study, two methods are used:

- Content analysis

- Using ethnographic data

Content analysis includes collecting related information and data from all relevant books, documents, published and unpublished research works available, online articles, notes etc. (Aminuzzaman, S., 1991). We have tried to use ethnographic data from two universities to represent the actual conditions experienced on the ground. The major limitation of the study is that it focuses only on two universities (BRAC University and NSU) which have established the Career Development Services (CDS) to provide a multifaceted support system to their graduates' career effectively among all other universities in the country. By analyzing secondary data, we have tried to focus on the roles of Career Development Services wing of a university i.e. BRAC University which may be useful to supplement the knowledge of different universities in building its students' healthier career lives.

\section{MULTIFACETED ACTIVITIES OF DEPARTMENT OF CAREER DEVELOPMENT SERVICES (CDS)}

In the beginning, CDS's sole responsibility would be limited to the students' affairs such as internship placement, career counseling, and job placement. Later, this wing may include some other activities like Professional Development Program, in which the main responsibilities of the department are to the professional development. CDS of different universities organizes executive development training, workshop, symposium and activities related to career and professional develop for students, employees of the university and also for corporate leaders. NSU is the first private university in Bangladesh that established the Department of Career and Professional Development Services (CPDS) to provide a multifaceted support system to its graduate's career. The other private university named BRAC University is seen very caring to support their students providing support on employment opportunities. 
Ethnography is a genre of writing that uses fieldwork to provide a descriptive study of human societies. Ethnography presents the results of a holistic research method founded on the idea that a system's properties can not necessarily be accurately understood independently of each other. The genre has both formal and historical connections to travel writing and colonial office reports. Several academic traditions, in particular the constructivist and relativist paradigms employ ethnographic research as a crucial research method. Many cultural anthropologists consider ethnography as the essence of the discipline.

Here, we shall try to discuss successful instances from two well-known private universities of Bangladesh (BRAC University and North South University) and also eminent universities from the world which may be invaluable for the students of different public and private universities in Bangladesh, if followed. The activities of CDS are as follows:

\section{A. Career Planning Activities:}

The Career Planning wing provides to all students and alumni of the university with internship, part-time \& full-time job-placement, career counseling, and job related database services.

\section{Career counseling}

The most important activity of CDS is Career Counseling. While entering into the competitive job market, Bangladeshi job seekers hardly find the right path which can help them to goal oriented career.

Here comes the importance of having a career goal. A career goal helps students to focus on what he/she wants to do for a living. A career goal can be a specific job he/she wants to do - such as doctor, teacher or engineer - or a career goal can be a particular field he/she wants to work in such as IT, Education etc. Rather than limiting one's future, a career goal may help him/her to discover career opportunities that he/she wouldn't have thought of otherwise. There are several job opportunities with any chosen career. For instance, if one chooses medicine as career, he/she may want to be a medical scientist or a doctor in public or private sector. Career resources are comprised of 3 important factors that are important for a job seekers to identify \& prepare accordingly. The factors are: Cover Letter Writing, Resume Writing and Interview Tips (Chowdhury, M. E., 2008). One-on-One consultations by the CDS staffs helps graduates to gain 
proper conception about career path focused on areas of strength or concern. CDS staffs are dedicated to guide students to recalibrate/ redirect.

\section{Writing resume}

Prospective graduates and alumni who have registered with the CDS are able to get help in resume writing. A resume is a targeted and concise summary of a student's qualifications and accomplishments. It is designed to draw attention of the reader to motivate them to short list a student for interview. All resumes should contain certain vital information including- (i) Career objective, (ii) Education, (iii) Representation of participation in career related activities, (iv) Eye-catching additional information, (v) Detailed personal information, (vi)Extra-curricular activities, (vii) References etc.

\section{Interview preparation}

Interview is a way to get to know each other for both a graduate and a potential employer. In order to do better in interview, CDS always can advise students by providing journals, newspapers, annual reports of companies to which students are interested to enrich knowledge and skills. CDS focuses on essential components for interview like (i) Good communication skills, (ii) Selfconfidence (being aware of own strengths \& weaknesses), (iii) Graduate's personality, (iv) Accomplishment, (v) Knowledge of organization with which one is interviewing etc.

\section{Preparing students for admission into foreign universities}

CDS assists students in several ways. Career counselors are to work with students individually to help them develop their career plans and to prepare them for applying in graduate schools abroad.

\section{International Opportunities}

The CDS can negotiate with the largest student organization in the world in exchanging students as interns on a regular basis. Possibilities of students and faculty exchanges in reputed international institutes are always explored.

\section{Graduate Survey}

The primary objectives of the graduate status survey are to identify the job openings trend in the country, to know the current employment status of the university graduates, to find out how well students are coping with the emerging job market and to see how capable the students are in obtaining graduate admissions in abroad. 


\section{Career Fair}

The initiative for arranging career fair is an effective means to find out bright and diligent graduates who can contribute in a better way to the development of Bangladesh. CDS regularly organizes career fair for the prospective job seekers in the country.

\section{Job Listing}

Throughout the year CDS has been continuously maintain high profile liaison with the corporate leaders though which it receives numerous job listings. It also tries to communicate the information about prospective candidates to the potential employers so that the employer can take initiatives to hire the graduates.

\section{Alumni Relations}

CDS always maintains relationships and liaise with the University Alumni Association, and it provides special services to the students who graduated from the university. Alumni relations help to link with different national and multinational agencies and negotiate with them for better career placement of the future graduates.

\section{Networking Programs}

In order to offer students opportunity to mingle with prospective employers, CDS arranges Networking Sessions at least once every semester. The purpose of such session is to create awareness amongst the students about the present employability criteria (Gerson, Donna, 2012).

\section{On-campus Employment}

Working while in college or university, beyond the financial gains, it can also give a student essential experience if he/she works and on campus employment has a positive impact on persistence, degree completion, timely graduation, and the probability of enrollment in professional schools. (www.career.arizona.edu/students/?uastuentemployment).

\section{Off Campus Employment}

There can be many benefits for students to work in the evenings and the weekends with off campus employers. In some cases, students may advise to work in any organization close to where they live. (Britannica Concise Encyclopedia. Copyright (C 1994-2008 Encyclopedia Britannica, Inc.) 


\section{B. Professional Development Activities:}

Throughout the year CDS coordinates a variety of events at both BRAC University and NSU. It offers executive development training, workshop, seminars, symposiums etc. for the corporate leaders in Bangladesh. The Professional development wing undertakes several seminars, corporatepresentations, and training programs for the faculty, graduates, staffs, and students. Business research, consultancy, publication of journals, and generating reports are other activities.

\section{Internship}

One of the major roles of CDS of BRAC University and NSU is to coordinate internship programs for students of various departments. The internship program offers supervised attachment with an organization for a certain period as required by the university and accepted by the employer. An internship program helps a student to get appropriate choice of career upon graduation and enable the intern to recognize the scope and complexity of a work environment and to build network with prospective field of career.

Here, we shall cite an example on how Career Management Services (CMS) process an internship placement in a private university of Bangladesh. In BRAC University, CMS maintain the following five steps activities-

Step 1: Career Service wing collects internship intention forms three weeks before the semester begins for the prospective interns.

Step 2: Once they processed student's applications letters to forward to the respective organizations of their choice, students have to allow at least three weeks to the organizations to respond after the letters are sent. Alternatively, if students wish to search for an internship placement at their own initiative, forwarding letters are made available. It is expected thereon to keep updated.

Step 3: Now it is up to the employers to shortlist CVs and call for an interview. Note that they may or may not call at all. There is no graduate that an interview call will secure a position. Office used to wait until all the organizations have responded. If all are responded negatively, office will place interns at their own choice of organizations.

Step 4: Once selected for an internship students are advised to submit a copy of the letter of contact to the office within 7 days of joining. No late 
submission is accepted. Once a placement is accepted, students have to complete 12 weeks of attachment with the organization.

Step 5: Once students have confirmed their registration and paid to the accounts, a copy need to be submitted to the office. Office has to attach intern with an Academic Supervisor for the next 12 weeks. In case of choice of advisor is at the discretion of the concerned department and not the student. Finally, office receives grades from academic supervisor and on-site supervisor and then students' grade are sent to the registrar's office.

The following figure will make clear the importance of CDS in internship program of BRAC University:

FIGURE 1: Internship placed by Career Services Office of BRAC University, 2008
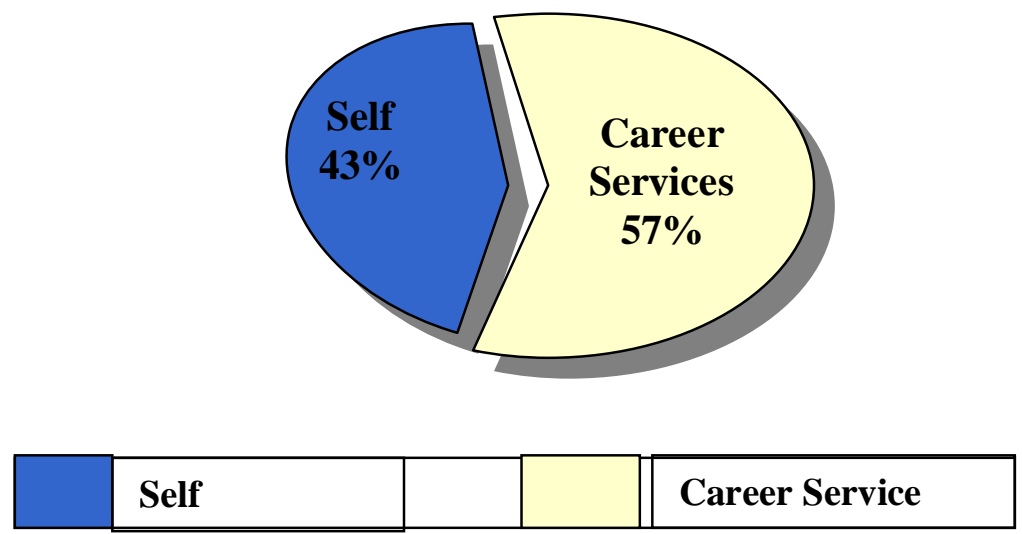

Source: Annual Report2010, BRAC University

A number of 179 BBA students registered for internship in 2008. All of them were placed for either internship or job in due time. On an average $57 \%$ of the intern placements were made by Career Service and $43 \%$ students managed placements positively by self-initiatives (Career Service Hand book, BRAC University, Dhaka, Bangladesh, 2010).

\section{Clubs, Organizations and Extra-curricular Activities}

Both of the universities have clubs, organizations and extra-curricular activities because they believe that diversified qualities are required in order to produce a quality $\mathrm{CV} / \mathrm{resume}$. One needs good grade as well as extra-curricular activities to strengthen the resume and makes it competitive, providing an edge over others. Extra-curricular activities involve club activities, social work, 
training, recreational activity, part-time jobs or any other form of activities that are outside the main curriculum. Generally, there is a restriction on the number of clubs a student can join at a time. In such cases, it is advisable to choose the clubs that will reflect upon that person's career.

\section{Workshop/Seminar}

To improve the presentation skills of students, BRAC University and NSU organize seminar, workshop on various issues. The office can lead the seminar and talk about different ways of being a good speaker in front of audiences and they can share their views and ideas among the participating students.

\section{Mock Interview}

Mock interview is organized at least twice a year by both of the universities to promote greater understanding of needs and issue with employment industry. The purpose of the interview can be strengthen the existing academia-corporate relationship and to (i) help students gain experience and practice in answering questions, which are likely to be asked by the recruiters during an actual job interview, (ii) facilitate collaborative arrangements for students' internship placement, (iii) understand employers' expectations about employability criteria.

\section{Examples of CDS' activities of two private universities in Bangladesh in brief:}

Career Development Services wing of NSU is known as Department of Career and Professional Development Services. CPDS organized almost 20 programs in the year 2008 that display its objectives well. On the other hand, Career Service Office of BRAC University organized almost 20 programs in the year 2008 that display its objectives, too. Some of them are as follows: 


\section{TABLE 1
PROGRAMS ORGANIZED BY CAREER DEVELOPMENT SERVICES WING OF NSU (CPDS) AND BRAC UNIVERSITY (CSO) IN 2008}

\begin{tabular}{|c|c|}
\hline $\begin{array}{l}\text { Programs organized by CPDS, } \\
\text { North South University }\end{array}$ & $\begin{array}{c}\text { Programs organized by CSO, } \\
\text { BRAC University }\end{array}$ \\
\hline $\begin{array}{l}\text { 1. Career Workshop on issues like, } \\
\text { "Resume Writing and How to } \\
\text { Prepare the Best Cover Letter". } \\
\text { 2. Internship Orientation. } \\
\text { 3. Mock interview of Recruitment, } \\
\text { Selection and Placement. } \\
\text { 4. Corporate presentation by } \\
\text { companies like, Grameenphone, } \\
\text { MGH Group, Standard Charter } \\
\text { Bank, Eastern Bank, HSBC } \\
\text { Bank, Westin Hotel, Maersk Line } \\
\text { etc. } \\
\text { 5. Workshops on effective teaching. } \\
\text { 6. Presentation of Standard } \\
\text { Chartered Bank Ltd. regarding } \\
\text { recruitment of Management } \\
\text { Trainee \& International } \\
\text { Graduates. } \\
\text { 7. Career Festival at NSU (Campus } \\
\text { Recruitment), Organized by } \\
\text { CPDS and bdjobs.com. } \\
\text { 8. Seminar on "Higher Studies in } \\
\text { Australia"-Organized by CPDS. } \\
\text { 9. Corporate Presentation and } \\
\text { Talent Search for Management } \\
\text { Trainee, by BRAC Bank. } \\
\text { 10. Presentation of Career in Media } \\
\text { and Airlines by JobsA1.com }\end{array}$ & $\begin{array}{l}\text { 1. "British American Tobacco's - } \\
\text { Battle of Minds Case } \\
\text { Competition" - A case study } \\
\text { competition for fresh graduates. } \\
\text { 2. BRAC Bank Road Show 2008- } \\
\text { The session gave insight on the } \\
\text { Management Trainee Officer } \\
\text { (MTO) recruiting procedure. } \\
\text { 3. Standard Charter Networking } \\
\text { Session 2008 on recruitment. } \\
\text { 4. On-campus career workshop } \\
\text { with Jobstreet.com. } \\
\text { 5. Session on presentation skills for } \\
\text { final year students. } \\
\text { 6. Seminar by Canadian High } \\
\text { Commission. } \\
\text { 7. Job-ICT Private Ltd. (JIPL) } \\
\text { Road Show on Soft Skills } \\
\text { Development } \\
\text { 8. Mini Job Fair Sponsored by } \\
\text { bdjobs.com. } \\
\text { 9. A workshop on scholarship } \\
\text { opportunities at Monash } \\
\text { University. } \\
\text { 10. Workshop on "Cracking } \\
\text { Assessment Center". }\end{array}$ \\
\hline
\end{tabular}

Sources: National Career Fair Bulletin (NSU) 2013, p. 40-41; and Career Service Handbook, 2010, BRAC University

\section{Success Story of CDS Employments Arrangement:}

The employment arrangement success of both the universities is presented in the following discussion. 
a) Employment arrangement by BRAC University:

TABLE 2

FULL-TIME EMPLOYMENT DATA OF BRAC UNIVERSITY, 2007

\begin{tabular}{|c|c|c|c|c|}
\hline Dept. & Employed & Unemployed & $\begin{array}{c}\text { Pursuing Higher } \\
\text { Education }\end{array}$ & $\begin{array}{c}\text { Total } \\
\mathbf{\%}\end{array}$ \\
\hline ARC & 75 & 25 & - & 100 \\
\hline BBA & 78 & 8 & 14 & 100 \\
\hline CS & 76 & 9 & 15 & 100 \\
\hline CSE & 83 & - & 17 & 100 \\
\hline Economics & 50 & 25 & 25 & 100 \\
\hline English & 37 & 36 & 25 & 100 \\
\hline Average \% & 66.5 & 20.6 & 19.2 & \\
\hline
\end{tabular}

Source: BRAC University Annual Report 2007, p.70

On an average $66.5 \%$ of the graduates during 2007 were employed while $19 \%$ on average were pursuing higher studies mostly on abroad, $20 \%$ of those who were unemployed so voluntarily (BRAC University Annual Report 2007, pg-70). In the year 2010 from the various departments of undergraduate program, about $66 \%$ students were employed in different sectors, $15 \%$ students were pursuing higher studies and $14 \%$ students remained unemployed who were still looking placement since they had just been graduated in December, 2010 which is shown in the following figure.

FIGURE 2: Full Time Employment data (undergraduate), BRAC University, 2010

\section{Full-Time Employment Data of Brac University Graduates, 2010 (Undergraduate)}

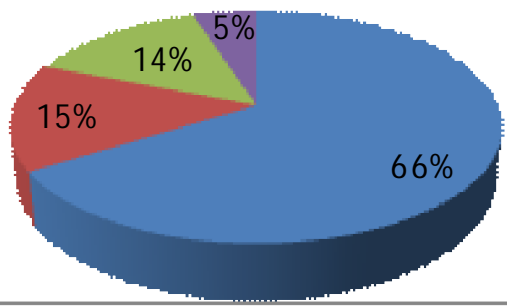

- Employed

Persuing Higher Education

- Unemployed

Data Not Found

Source: BRAC University Annual Report 2010, p.171 


\section{b) Employment arrangement by NSU:}

Employment of NSU graduates shows a steady and significant increase over the years 1996 to 2007 . Every year less and less graduates remain unemployed. Most of them are employed or pursuing higher education (Chowdhury, A. Hannan and Batul Towfique, 2008). The increment of NSU students' employment is presented in the following figure.

FIGURE 3: Comparison of NSU Graduate Employment over the years 1996 to 2007

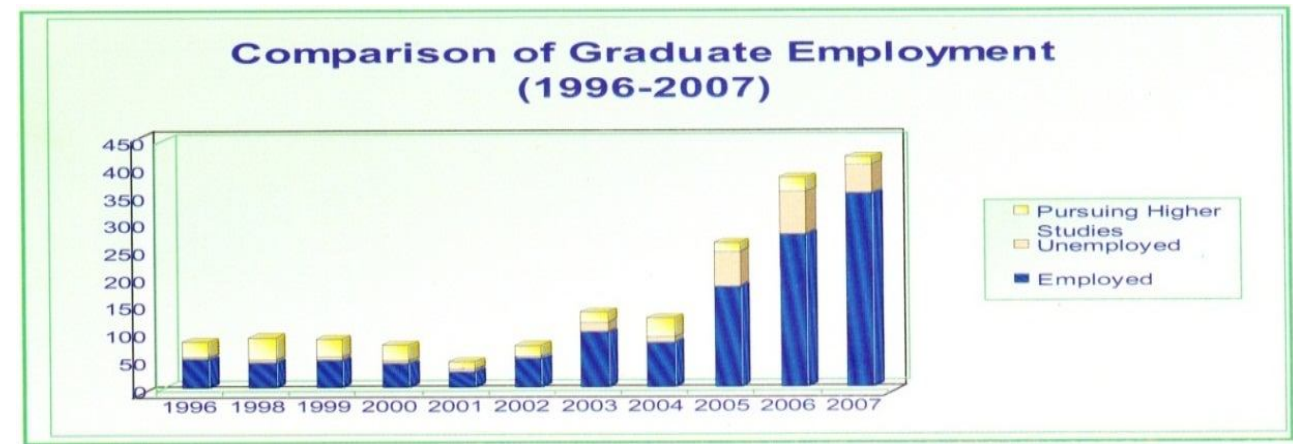

Source: Chowdhury, A H and Batul Towfique (2008), National Career Fair Report 2008,

NSU, October, 2008, p.47.

Of the 380 graduates in 2006, $73.16 \%$ are employed, $20 \%$ unemployed and $6.84 \%$ were pursuing their higher education. 2007 data show significant increase in the employment status of NSU students. Of the 351 graduates, $83.97 \%$ are employed, $12.44 \%$ are unemployed and $4.3 \%$ are pursuing their higher education which is shown in the following figure.

FIGURE 4: Increasing Employment Trend of NSU Graduates, 2006 \& 2007

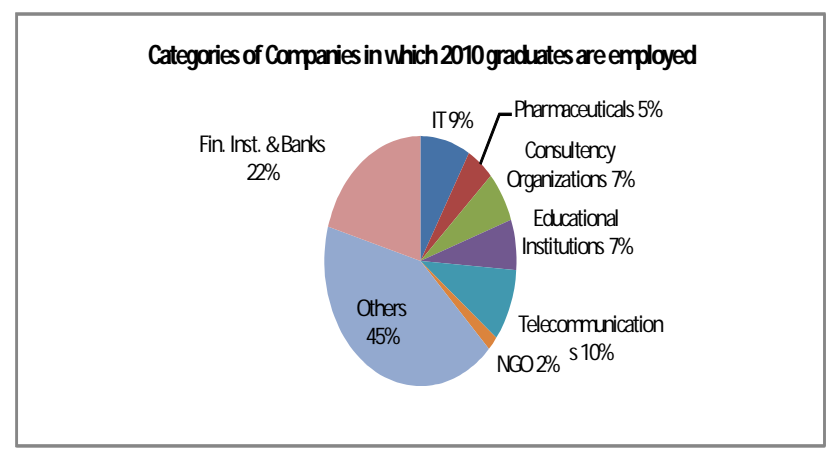




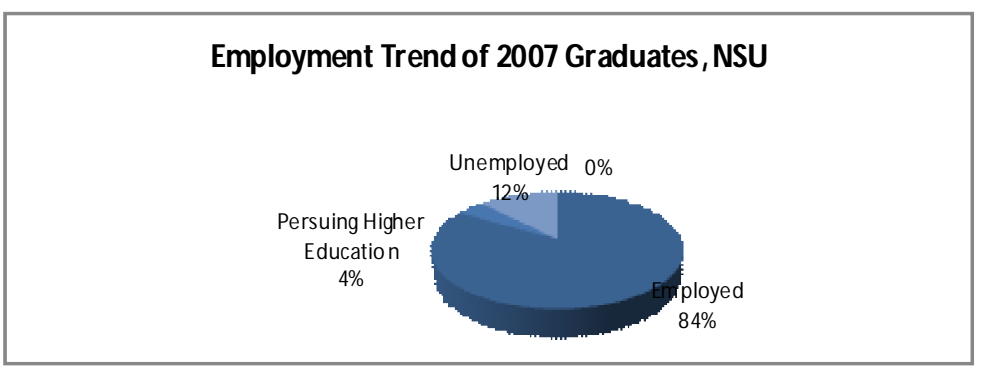

Source: National Career Fair Report 2008, p.46

Financial institutions, banks, telecommunication and IT remain the most prominent employers of NSU graduates. They are also employed in other sectors such as education, NGOs and media (M K Miah and R T Malik, 2013). Graduate employment of NSU by categories of companies is given below:

FIGURE 5: Graduate Employment of NSU by Categories of Companies in 2009 and 2010

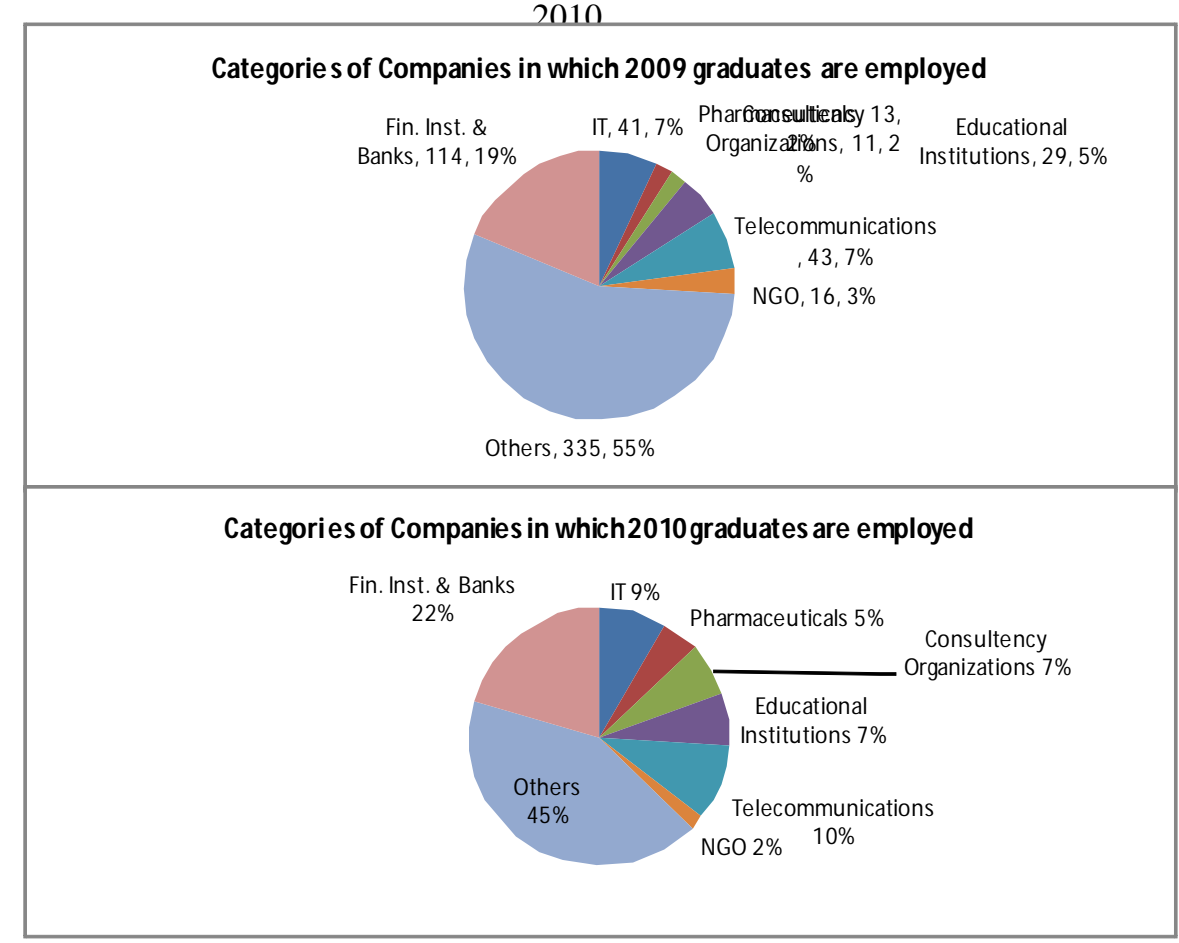

Source: Trend of NSU Graduates: Employment Status, 8th National Career Fair Handbook, June, 2013, p.35 
Figure 5 shows the percentage of NSU graduates employed in different categories of companies in the years 2009 and 2010.

\section{EMPIRICAL FINDINGS}

Bangladesh is a developing country, and by definition, poor. Here students get the opportunity to study through great competition in different universities and colleges. They suffer from severe unemployment problem and face dreadfully high competition to get a job. Though somebody gets a job, it may not be after liking due to inadequacy of job facilities. In this situation, students are to help in developing themselves for attaining professional goal.

This study examines the various missions of professional development activities of BRAC University, Dhaka, Bangladesh and North South University, Dhaka, Bangladesh. It has been found that the chief mission of a Career Development Services (CDS) wing of a university is to help students by developing their potentials for competitive job markets and providing them with employment opportunities in a true manner.

Considerable attention is paid by BRAC University and NSU to the professional skills development program i.e. career counseling, writing resume, job listing, preparing students for higher studies in foreign universities, finding part-time \& full-time employment, maintaining alumni relations etc.

At present, it has become the intention of students' admission that they want to be admitted to those universities which help their graduates in getting suitable jobs.

This study has also found that universities are making the wisdom, talents and intelligence of the graduates more useful to present job markets as well as to the potential employers.

CDS is exceedingly required for a substantial number of bright, eager and diligent young graduates interacting with career professionals, diverse business entities and potential employers. CDS has great contribution to the success of BRAC University and North South University in Bangladesh. 


\section{CONCLUSION}

This study emphasizes upon the significance of students' professional development by using their wisdom, talents and intelligence. The main focus of a university is teaching and learning, research and discovery, and outreach and engagement. But in course of time university also creates, conveys, and applies knowledge to expand personal growth of the students and improve quality of life. Because, without imparting qualitative education and proper counseling a fresh graduate may lose the right way to approach in getting a better livelihood and build healthier career. The university helps in shaping students' professional life in the way of achieving the goal. CDS plays a vital role in blending the talented university graduates with prospective employers. BRAC University and NSU are doing an excellent job by exposing the graduates with existing job market. They have become successful to get attention of many large employers in home and abroad.

Hence, CDS operations may be invaluable for different public and private universities in Bangladesh, if followed. It may be a significant initiative by the universities considering the importance in educating Bangladeshi youth, helping their graduates to get the right jobs and contributing to the society using their potentials. Consequently, the university authorities (Public and Private) should not overlook activities related to career and professional development. CDS initiative of BRAC University and NSU may help universities having no or little experience in this regards. This study may help to supplement the knowledge of different stakeholders in general and policy researchers in particular. 


\section{REFERENCES}

David A. DeCenzo and Stephen P. Robbins (2007), Fundamentals of Human Resource Management (USA: John Wiley \& Sons, Inc. 2007) pp. 232237.

Leila D. Landicho (2001),Sustainable Upland Development in the Philippines: Lessons from a Multi-Sectoral Partnership for Promoting CommunityManaged Agro-Forestry Extension Services, University of the Philippines. pp.1-2

D.T. Hall (1976), Career in Organizations (Santa Monica, CA: Good year Publishing, 1976; Santa Monica, (1977)Improving Life at Work: Behavioral Sciences Approaches to Organizational Change, pp. 341-355.

J.H. Greenhaus (1987). Career Management, New York: Dryden Press, 1987, p.6.

Career Service Handbook, BRAC University (2010).Find the difference between a job and Career, p. 5.

Miah, M Khasro (2013), Career and Professional Development Services (NSU), 8th National Career Fair Bulletin, p. 3.

HARVARD University, The mission statement :

http://www.campusservices.harvard.edu/ mission-statement

Educational Mission of Massachusetts Institute of Technology (MIT): web.mit.edu/mission.html p.2

Luis R. Gomez-Mejia (2000), Arizona State University, David B. Balkin, University of Colorado, Boulder, Robert L. Cardy, Arizona State University. "Managing Human Resources (Fourth Edition)”, p.-206

Yamamoto, T. (1993).Recruiting System badly designed, badly run, unlikely to change ;Tokyo Business Today, 52-54.; 9

Creswell, John W. (2003), Research Design: Qualitative, Quantitative and Mixed, Sage Publications. 
Aminuzzaman, S. (1991),Introduction to Social Research, Bangladesh Publishers, Dhaka.

M E Chowdhury Shyameem (2008).“CV Writing and Winning Interview”, National Career Fair Report 2008, NSU, p.51

Chowdhury, A. H. (2010), Role of CPDS at NSU, NCF Handbook, p. 18

BRAC University Annual Report 2010, Full Time Employment data (Undergraduate) p.171

Donna Gerson (2012)-“Building Career Connections: Networking Tools for Law Students and Lawyers", p.2

The University of Arizona Career Services, (2009), Career Counseling \& Other Services, Student Union Memorial Center, 1303 E University Blvd., Suite 411, Tucson, AZ. Vol-01

Britannica Concise Encyclopedia (Copyright (C) 1994-2008), Encyclopedia Britannica, Inc. Britannica.com.

BRAC University Annual Report 2007, p.70

Chowdhury, A H and Batul Towfique (2008), National Career Fair Report 2008,NSU, October, 2008, Dhaka, pp.38-50

M K Miah and R T Malik (2013), Trend of NSU Graduates: Employment Status, Success and Future Prospects, 8th National Career Fair Handbook, June, 2013, pp.26-37 